\title{
SOMETHING WENT WRONG: ON THE BRONZE CHAIN-BELT REJECTS FROM ČEJKOVICE (HODONÍN DISTRICT, CZ) ${ }^{1}$
}

\author{
PETRA GOLÁŇ V Á - M I L O Š H L A A
}

In the Central European La Tène period, there is only relatively very scarce evidence of bronze smelting in the form of half-finished products and rejects; the reason for this absence may be their proactive recycling. They only appear in greater quantities from LTC; it is also when we can date five chain-belt elements from Čejkovice presented in this paper. Other evidence of bronze smelting (crucibles, bronze lumps, casting spills) is not rare in South Moravia (it is documented in as many as seven sites in the surroundings of Čejkovice only) prompting considerations on the (de)centralisation of bronze working. At the current state of knowledge, bronze smelting seems to have been quite decentralised in Moravia in the $3^{\text {rd }}-2^{\text {nd }}$ centuries BC. Therefore, it does not seem to have been concentrated only in large agglomerations; for the moment we cannot say much in this respect about other regions including Central Moravia with Němčice nad Hanou.

Keywords: South Moravia, Late Iron Age, non-ferrous metallurgy, chain-belts, craft organisation.

\section{INTRODUCTION}

Bronze smelting and the manufacturing of bronze artefacts was a specialised craft in the La Tène period. The research into this production activity has recently focused on the analyses of the alloys in order to determine their provenance using trace element patterns and lead isotope analysis (cf. Danielisová et al. 2017; 2020; 2021; Danielisová/Strnad/Mihaljevič 2018). As a matter of fact, in contrast to the large quantities of final products, the evidence of their manufacture is relatively rare. Apart from actual manufacturing structures, the past bronze smelting areas can be signalled by raw materials and production waste (rejects, remains of investment moulds) as well as by instruments (crucibles, flan moulds, casting moulds) and half-finished objects (cf. Venclová 2001, 5; Záruba 2015). Among these, rejects and half-finished objects are relatively rare (Schäfer/Scharff 2003). Therefore, the five chain-belt elements from Čejkovice (Fig. 1: 1) presented in this paper contribute considerably to our present knowledge and at the same time make us ponder the degree of (de)centralisation of bronze smelting in the (Middle and Late) La Tène period (not only) in South Moravia.

\section{THE FINDS}

The artefacts listed below are kept in the Regional Museum in Mikulov, acc. no. 37/2021.
1. Chain-belt pendant - miscast (Fig. 2: 1). A strongly articulated chain-belt pendant, the base is decorated with three incised lines creating a triangle. The suspension eyelet did not cast - only its very base is present. Casting burrs on the lower part of the pendant resulting from the leaking mould were not cleaned off. Length (excluding the eyelet stub) $18 \mathrm{~mm}$, max. diam. $12.4 \mathrm{~mm}$.

2. Chain-belt link - miscast/half-finished? (Fig. 2: 2). A complete chain-belt link with a central knob flanked from each side with a fine rib; there are two holes in each of the side-plates. The edges of the side-plates feature unremoved casting burrs and sprue remains. Length $25.4 \mathrm{~mm}$, width $14 \mathrm{~mm}$ (including the sprue remains), the central knob dimensions $11.4 \times 10.6 \mathrm{~mm}$.

3. Chain-belt fragment - miscast (Fig. 2: 3). A side-plate with a bronze knob on the transition to the central part and on the outer longer side. The three holes in the plate are only hinted at by divots - they do not go through. Dimensions $16 \times 11.8 \mathrm{~mm}$.

4. Chain-belt fragment - miscast (Fig. 2: 4). A side plate of a belt link whose central part failed to cast. There are uncleaned burrs on the plate and a rest of a sprue on its outside. The originally intended three holes are preserved only as divots on only one side of the plate. Plate dimensions $18 \times 10.6 \mathrm{~mm}$.

5. Chain-belt fragment - miscast (Fig. 2: 5). A chain-belt side-plate with a portion of the adjacent shaft at which point the object is broken. The cast bronze failed to fill-in one of the plate's corners leaving one of the three holes open; there are uncleaned burrs around the plate. Out of the intended three holes two were cast as mere divots, the third one did cast hollow but also open to the side. Plate dimensions $18.4 \times 9.3 \mathrm{~mm}$.

\footnotetext{
1 The paper was written thanks to Grant Agency of Masaryk University (MUNI/A/1122/2020). We are grateful to the finder Jan Ivančic and our colleague František Trampota (Regional Museum in Mikulov) for enabling us to publish the finds exposed in the exhibition Keltové pod Pálavou.
} 


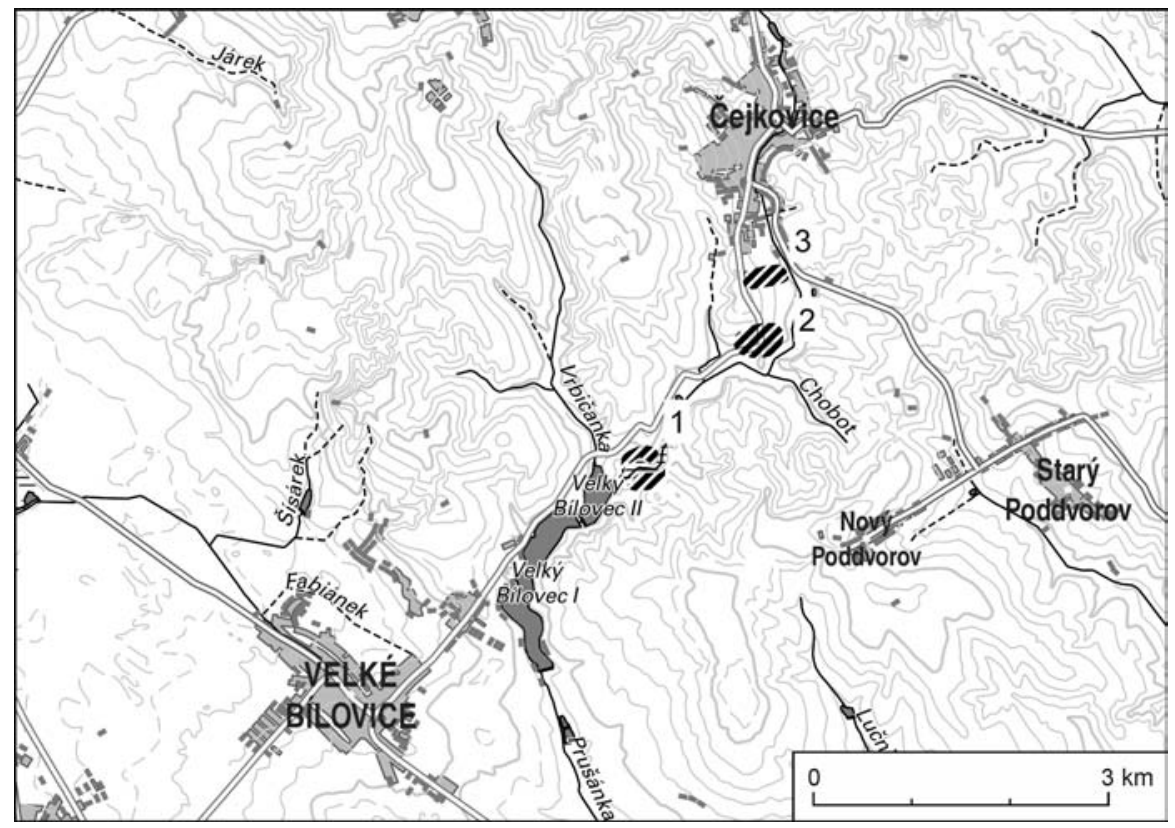

Fig. 1. Čejkovice, Hodonín distr. La Tène period settlement in the municipality territory which can be precisely localised. 1 - Úzké úlehle, Nivy/Niva pod silnicí; 2 - Padělky od Chobota; 3 - Haltýře/Padělky u Mlíčka (layout T. Tencer).

\section{TERRITORIAL CONTEXT}

The objects were discovered on the north-west slope of a nameless hill (altitude $232 \mathrm{~m}$ a.s.l.) south of Čejkovice near the Prušánka stream which drains into the Velký Bílovec pond several hundred metres further downstream. Based on the information provided by the finder, Jan Ivančic, four of the artefacts were found on the stream's left bank at the Úzké úlehle location while one comes from the Nivy/Niva pod silnicí location on the right bank (Fig. 1: 1). ${ }^{2}$ Traces of La Tène period activities are thus present on both banks of the stream overlooking the area once occupied by a currently defunct - pond documented in the maps of the $2^{\text {nd }}$ Military Mapping Survey of the Austrian Empire (1816) as the 'Helesni Teich'; its original location can still be made out in the landscape by its water-logged nature.

No La Tène period artefacts have so-far been published from the find spot. However, a La Tène period settlement was identified in 1970 a mere $2 \mathrm{~km}$ further north in the Čejkovice territory in the Padělky od Chobota location (Fig. 1: 2). A pottery crucible for bronze smelting was even discovered in one of the features (ger. Grubenhaus) excavated there (Čižmár 2002a, 243, 248, fig. 1: 1; Klanica 1971; Waldhauser 1986, 207, fig. 5: D; cf. also e.g. Meduna
1980, 66; Škojec 2000, 407, 408, fig. 3: 15-18; 4: 1-9under the name Padělky u Mlíčka; Čižmářová 2004, 162). A La Tène settlement with the remains of at least 28 dugout features dated to LTB-C were documented when intersected by a linear infrastructure trench some $800 \mathrm{~m}$ north of the site of ČejkovicePadělky od Chobota in the Haltýre location (though based on the cadastral map they rather belong to the Padělky u Mlíčka location; Fig. 1: 3; Kostrouch 2011).

It is also worth realising that it was still in the Čejkovice territory (in an unknown location, allegedly in a field) that a dog figure was found (Červinka 1902, 140, fig. 70) dated to the La Tène period (Čižmár 2012, 151, 160, fig. 13: 15; Čižmářová 2004, 162 with a fig.; cf. Škojec 2000, 409, fig. 4: 20).

\section{TYPOLOGICAL}

\section{AND CHRONOLOGICAL CONTEXT}

All four chain-belt links from Čejkovice can most probably be classified as the type with a central knob. A single one of them (Fig. 2: 2) belongs to the relatively rare variety with ribs flanking the knob and double hole in the side plates (Mangel/Jošková 2019, fig. 3; 4; tab. 1). Three fragments (Fig. 2: 3-5) can be classed as the variants with triple holes in the side plates well documented in Moravia in the

\footnotetext{
2 Another four half-finished chain-belt links and a belt pendant were discovered at the Úzké úlehle location during the final works on the present paper. It could not be taken into consideration here.
} 


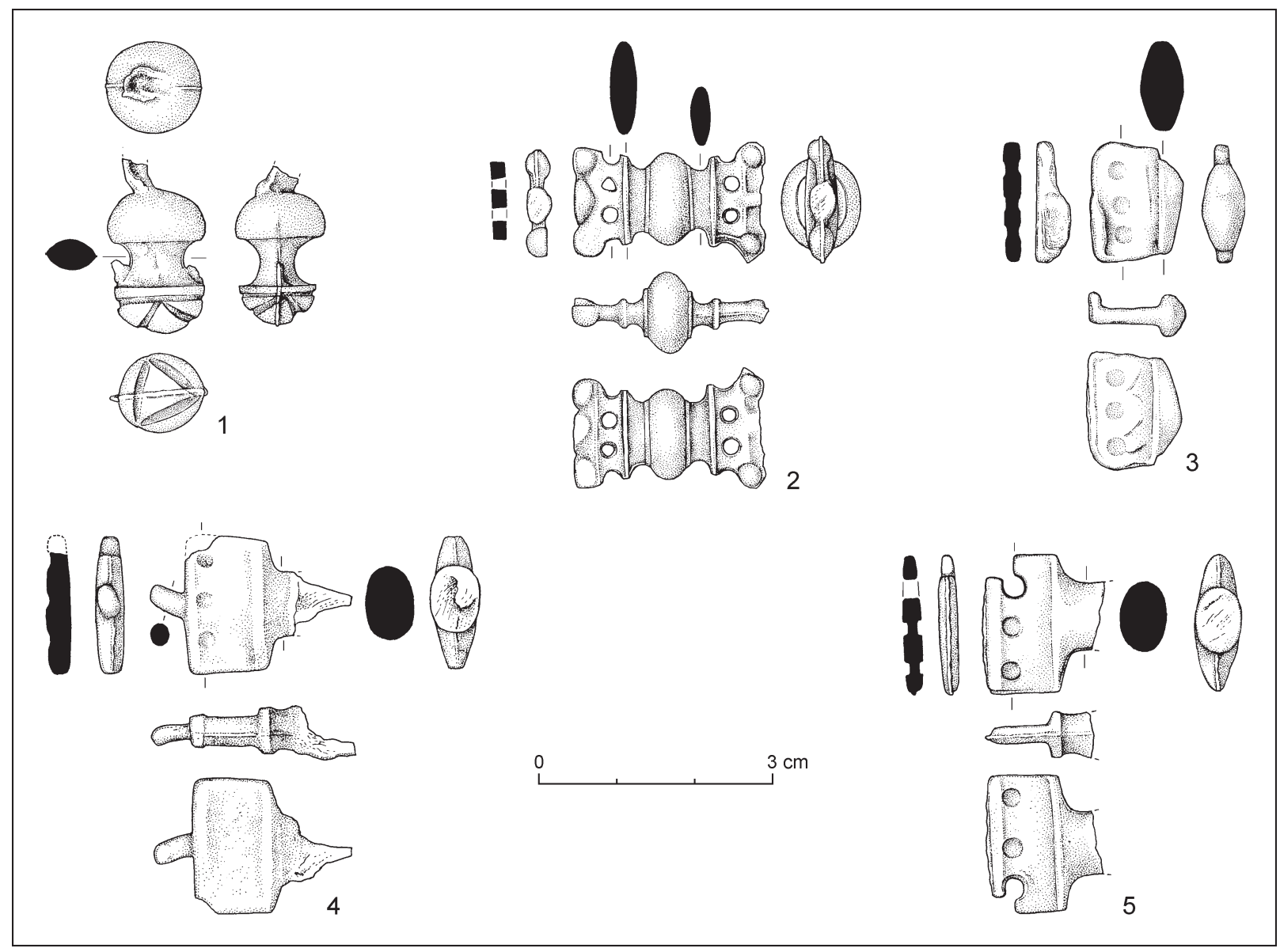

Fig. 2. Čejkovice-Úzké úlehle, Nivy/Niva pod silnicí, Hodonín distr. Half-finished artefacts/rejects of chain-belt components. 1 - pendant; 2-5 - chain-belt links (drawing by S. Plchová).

regions of Břeclav and Hodonín (Goláňová et al. 2020, 31, 32, fig. 2: 2; 3: 12; 4: 10, 11; 5: 7; Mangel/Jošková 2019, fig. 4; tab. 1) while also common in south-west Slovakia and Lower Austria (Mangel/Jošková 2019, fig. 4; tab. 1). Chain-belt links of this type are also among the best represented in Němčice nad Hanou in Central Moravia (Čižmář/Kolníková/Noeske 2008, 661, fig. 8: 1-3). They can be broadly dated to LTC2 with possible continuity to LTD1 (Mangel/Jošková 2019, 469).

The chain pendant from Čejkovice (Fig. 2: 1) is very close in its shape and dimensions to the finds from Lednice-Podholmy and Želetice (Goláňovál Kysela 2019, 72, 79, fig. 2: 3) though in the case of the Čejkovice pendant we cannot decide whether the suspension eyelet was intended to be rectangular as in the other two cases. The date of these pendants is most probably identical to that of the chain-belt links (most likely LTC2), since pieces with this decoration are absent in burials but present in Němčice nad Hanou, whose occupation peaked in LTC2 (Čižmář et al. 2008, fig. 4: 3; Čižmář/Kolníkovál
Noeske 2008, fig. 8: 14). They are documented not only in Moravia but also in Bohemia and southwestern Slovakia (cf. Goláňová/Kysela 2019, 79 with an overview of the sites).

\section{MANUFACTURING CONTEXT}

All the presented finds from Čejkovice bear traces of miscasting and uncleaned casting residues. The rough castings were obviously not further worked once the failure was discovered. Casting the links by means of a sprue in the centre of the side plates (cf. the unremoved sprue - Fig. 2: 4) was apparently a common practice as its traces have been observed in various (unfinished) semiproducts/rejects (Hrušky-Tvrdonické Podsedky: Goláňová et al. 2020, fig. 4: 1; Němčice nad Hanou: Čižmář/Čižmářová/Kejzlar 2011, fig. 5: 10; Čižmár̆l Kolníková/Noeske 2008, fig. 9: 3). The slanted orientation of the sprue may suggest that the links were cast in series in a single complex mould in 
which the radial sprues distributed the metal to the individual imprints of the objects to be cast; such a procedure is documented in other cases (cf. the mould for casting brooches from Bibracte: Guillaumet/Labaune 2011, 898, ill. 6).

The assemblage of five rejects from Čejkovice clearly suggest a (nearby?) workshop manufacturing bronze artefacts/smelting bronze. The objects are either production waste (testifying thus to chain-belt manufacturing at the site) or raw material intended for further recasting. Two fragments (Fig. 2: 4,5) come from links of identical dimensions and may thus have resulted from a single event (failed casting of links of a single chain-belt); alternatively, they could represent two marginal mishaps in bulk of quality output which were then set aside for recasting. More information on the raw material could be gained in the future from composition analyses (Danielisová et al. 2017; 2021; cf. Goláñová et al. 2020, 24-29) even though in mass production the alloy composition of the various segments of a single chain-belt could have varied (Čižmár et al. 2020, 115, tab. 1). The sudden increase in the manufacture of bronze objects, first and foremost chainbelts, in LTC which is reflected in the quantity of their finds in metal detector surveys (Danielisová et al. 2018; Goláñová et al. 2020) brought about a large demand for the raw material and necessitated its massive recycling (Danielisová et al. 2017, 92-96; Kysela 2016, 206).

In South Moravia, bronze casting rejects were also documented in Hrušky-Tvrdonické Podsedky (Goláñová et al. 2020, 32, fig. 4: 1) and we can also add those from Bernhardsthal in the Austrian part of the Thaya/Dyje valley (Allerbauer/Jedlicka 2000, 616, fig. 8: 2). ${ }^{3}$

Bronze casting rejects are not very common finds - most probably because they were being systematically recycled, in particular in the early phases of the La Tène period (cf. Goláňová 2018, 80-82). It is not until LTC that rejects as well as half-finished artefacts appear in greater amounts. The finds described so-far come mainly from large agglomerations (Němčice nad Hanou: Čižmář/Kolníková/Noeske 2008, 662, fig. 9: 2-5; Nowa Cerekwia: Rudnicki 2014, 425, fig. 4: 7; Berching-Pollanten: Schäfer 2010, 172, fig. 129) and medium-size settlements accredited with central functions (Žehuň: cf. Danielisová et al. 2018, 149). They are also present at some oppida - e.g. at Třísov in which other evidence of bronze casting is documented (crucibles, moulds - Danielisová et al.
2017; Kysela 2017, 468) or at Staré Hradisko (Čižmár 2002b, fig. 6: 2; 7: 1, 2; 8: 1). At Stradonice, bronze casting rejects and half-finished objects have not been published in much detail (cf. Píc 1906, pl. LVIII: 5, 6 - sprue cones, 13 - crucible; cf. Venclová ed. 2008, app. 5: 1) ${ }^{4}$ with the exception of the last excavations in which one semi-finished object and several crucible fragments have been unearthed (Rybová/Drda 1994, 116, fig. 39: 7).

The most common finds evidencing non-ferrous metallurgy are crucibles. In Moravia they are quite significantly represented in the regions of Břeclav and Hodonín: out of the 13 sites in which crucibles have been found, listed by Miloš Čižmář in 2002, eight are localised in this territory (Čejkovice, Křepice, Mistřín, Mutěnice, Pavlov, Pouzdřany, Tvrdonice, Velké Hosterrádky); the items from Pouzdřany and Velké Hostěrádky as well as some of the numerous crucibles from Mistrrín proved to have been used for smelting gold (Čižmár̆ 2002a, 243-247).

Other evidence of smelting in lesser known sites in South Moravia include bronze lumps and casting spills from Lednice-Herdy and Lednice-Podholmy (their dating to the La Tène period is very likely based on the alloy composition - Goláňová/Kysela 2019, 74, 81, fig. 2: 12, 13).

The final piece of evidence of bronze metallurgy consists of - at least partly - moulds for casting specific artefacts. Several items of this kind are documented at the oppidum of Staré Hradisko (Čižmár 2002b, fig. 6; 7: 3-9) though similar finds have come to light also in other settlement types (cf. Milonice: Lečbych/Mikulková 2014, 388, 399, fig. 21: 4) including some from the beginning of the La Tène period (Modrá: Goláňová 2018, 81, fig. 32: 1; Břeclav region - Pavlov: Horálková 1990, 207, 209, fig. 1: 4).

\section{CONCLUSION}

Finds which can be linked with smelting activities are not rare in the regions of Břeclav and Hodonín. Only the territory of ca. $15 \mathrm{~km}$ around Čejkovice-Úzké úlehle, seven other sites can be listed which produced other evidence of nonferrous metallurgy; without exception they are open lowland settlements (Fig. 3; Čejkovice-Padělky od Chobota, Lednice-Herdy, Lednice-Podholmy, Mistřín, Mutěnice, Tvrdonice, Velké Hostěrádky). Although some of these finds do not date to the same phase as the Čejkovice-Úzké úlehle rejects

\footnotetext{
3 Michelstetten in Lower Austria yielded four crucibles and a half-finished object with uncleaned burrs (Trebsche 2010, 81, pl. 80; Fn. 10897).

4 The published images suggest that we are dealing here with material for recasting rather than with rejects.
} 


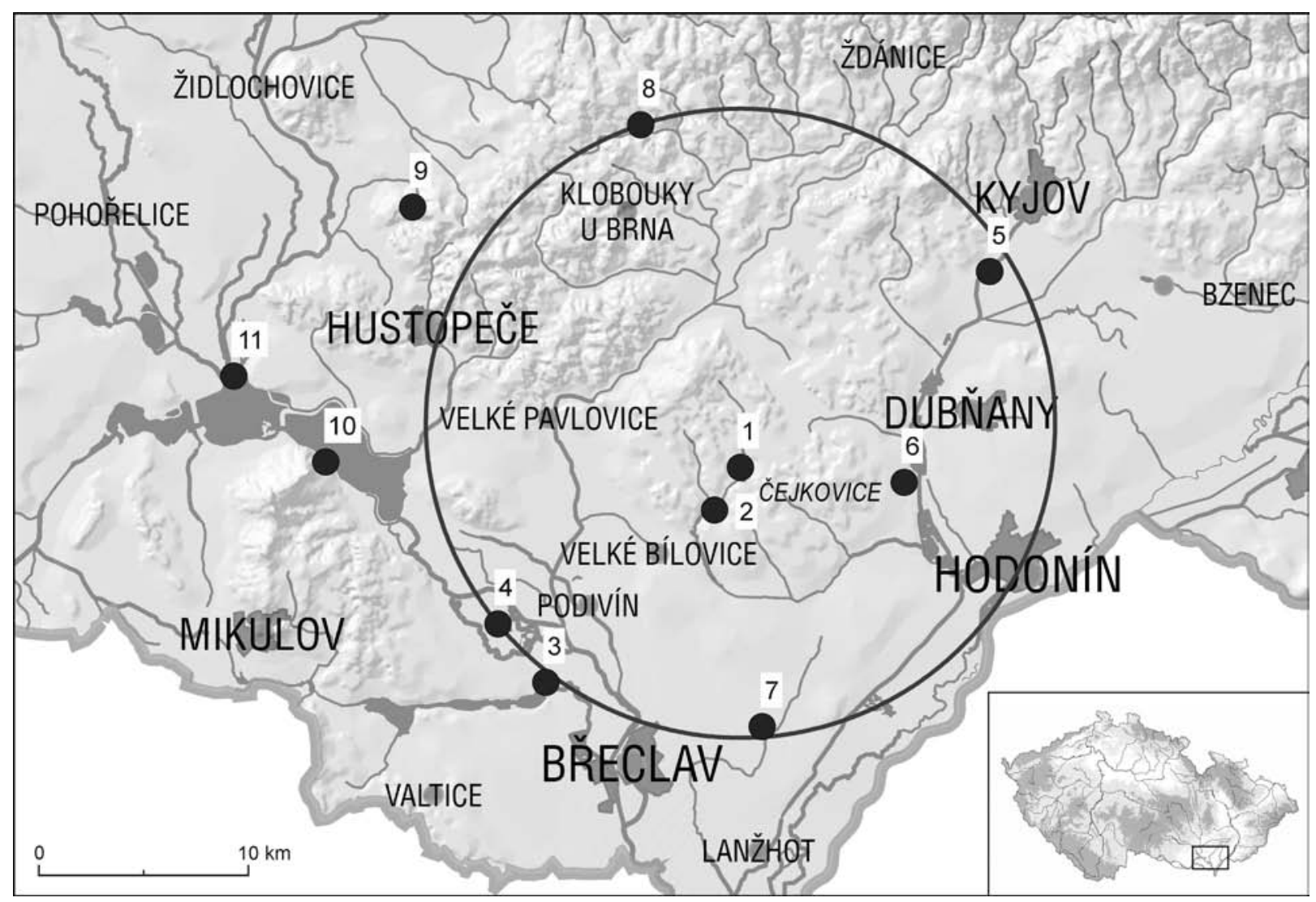

Fig. 3. The La Tène period sites in South Moravia (within $15 \mathrm{~km}$ of Čejkovice) with evidence of non-ferrous metallurgy. 1 - Čejkovice-Padělky od Chobota (crucible); 2 - Čejkovice-Úzké úlehle, Nivy/Nivy pod silnicí (half-finished artefacts/ rejects); 3 - Lednice-Herdy (bronze lump); 4 - Lednice-Podholmy (sprues); 5 -Mistřín (crucibles); 6 - Mutěnice (crucible); 7 - Tvrdonice (crucible, rejects); 8 - Velké Hostěrádky (crucible); 9 - Křepice (crucibles); 10 - Pavlov (crucibles, casting mould); 11 - Pouzdřany (crucible). Layout T. Tencer.

(the Pavlov crucibles date at the latest to the beginnings of LTB: Čižmář 2002a, 248, fig. 2: 1, 2) it is clear that at the present state of knowledge we can postulate rather decentralised smelting activities in the $3^{\text {rd }}-2^{\text {nd }}$ century BC Moravia. Therefore, this craft need not have been by any means associated only with large settlements (for Lower Austria cf. Trebsche et al. 2020, 477); it is not clear what the situation was in other regions including Central Moravia with Němčice nad Hanou.

\section{BIBLIOGRAPHY}

Allerbauer/Jedlicka 2000 - S. Allerbauer/F. Jedlicka: KG Bernhardsthal, MG Bernhardsthal, VB Mistelbach. Fundberichte aus Österreich 39, 2000, 614-616.

Červinka 1902 - I. L. Červinka: Morava za pravěku. Vlastivěda moravská. I. Země a lid. Brno 1902.

Čižmář 2002a-M. Čižmář: Nálezy tyglíků na laténských nížinných sídlištích na Moravě. Pravěk. Nová rada 12, 2002, 243-255.

Čižmář 2002b - M. Čižmář: Ökonomische Struktur des Oppidums Staré Hradisko. In: C. Dobiat/S. Sievers/ T. Stöllner (Hrsg.): Dürrnberg und Manching. Wirtschaftsarchäologie im ostkeltischen Raum. Akten des Internationalen Kolloquiums in Hallein/Bad Dürrnberg vom 7. bis 11. Oktober 1998. Kolloquien zur Vor- und Frühgeschichte 7. Bonn 2002, 297-313.
Čižmář 2012 - M. Čižmář: Nálezy drobné lidské a zvířecí plastiky z Moravy. In: G. Březinová/V. Varsik (eds.): Archeológia na prahu histórie. Kživotnému jubileu Karola Pietu. Archaeologica Slovaca Monographiae. Communicationes 14. Nitra 2012, 145-173.

Čižmář/Čižmářrová/Kejzlar 2011 - M. Čižmář/J. Čižmářová/ J. Kejzlar: Detektorová prospekce archeologických lokalit na Moravě v roce 2010. Přehled výzkumù 52, 2011, 86-95.

Čižmář et al. 2008 - M. ČižmářrJ. Čižmářová/J. Kejzlar/ E. Kolníková: Detektorová prospekce lokalit z doby laténské na Moravě. Přehled výzkumů 49, 2008, $125-131$.

Čižmář et al. 2020 - I. Čižmář/B. Mikulková/M. Kmošek/ M. Chovanec/J. Kala: Dva mimořádné hroby z latén- 
ského pohřebiště v Rousínově. Přehled výzkumů 61, 2020, 105-122.

Čižmář/Kolníková/Noeske 2008 - M. Čižmář/E. Kolníková/ H.-Ch. Noeske: Němčice-Víceměřice - ein neues Handels- und Industriezentrum der Latènezeit in Mähren. Vorbericht. Germania 86, 2008, 655-700.

Čižmářová 2004 - J. Čižmářová: Encyklopedie Keltů na Moravě a ve Slezsku. Praha 2004.

Danielisová et al. 2017 - A. Danielisová/J. Kysela/M. Mihaljevič/J. Militký: Metal working at the oppidum of Třísov, South Bohemia - A review. In: J. Kysela/ A. Danielisová/J. Militký (eds.): Stories that made the Iron Ages. Studies in Iron Age Archaeology dedicated to Natalie Venclová. Prague 2017, 83-99.

Danielisová et al. 2018 - A. Danielisová/J. Kysela/T. Mangel/R. Kyselý/J. Militký: Iron Age site in Žehuň, Central Bohemia. An open settlement with central functions. Památky archeologické 109, 2018, 127-178.

Danielisováet al. 2020 - A. Danielisová/D. Bursák/L. Strnad/ J. Trubač/H. Čižmářová/D. Daněček/K. Smíšek: Rituals, Hoards or Travellers? Archaeometry of the Iron Age Bronze Wheel Amulets. Interdisciplinaria Archaeologica. Natural Sciences in Archaeology 11, 2020, 33-45.

DOI: http://dx.doi.org/10.24916/iansa.2020.1.3

Danielisová et al. 2021 - A. Danielisová/P. Pajdla/D. Bursák/L. Strnad/J. Trubač/J. Kmošek: Claiming the land or protecting the goods? The Duchcov hoard in Bohemia as a proxy for 'Celtic migrations' in Europe in the $4^{\text {th }}$ century BCE. Journal of Archaeological Science 127, 2021.

DOI: https://doi.org/10.1016/j.jas.2020.105314

Danielisová/Strnad/Mihaljevič 2018 - A. Danielisová/ L. Strnad/M. Mihaljevič: Circulation Patterns of Copper-Based Alloys in the Late Iron Age Oppidum of Tř́isov in Central Europe. Metalla 24, 2018, 5-18.

Goláňová 2018 - P. Goláňová: The Early La Tène Period in Moravia. Studien zur Archäologie Europas 32. Bonn 2018.

Goláňová et al. 2020 - P. Goláňová/B. Komoróczy/ M. Kmošek/E. Kolníková/M. Vlach/M. Zelíková: New Metal and Glass Finds from the Late Iron Age in South Moravia. The Contribution of Citizen Science to Knowledge of the La Tène Settlement Structure in the Břeclav Region. Přehled výzkumu 61, 2020, 9-41.

Goláňová/Kysela 2019 - P. Goláňová/J. Kysela: What can the dwarfs tell? On settlements and anthropomorphic statuary in La Tène Southern Moravia. In: N. Beljak Pažinová/D. Repka (red.): Sedem kruhov Jozefa Bujnu. Studia Historica Nitriensia 23. Supplementum 2. Nitra 2019, 71-92.

DOI: https://doi.org/10.17846/SHN.2019.23.S.71-92

Guillaumet/Labaune 2011 - J.-P. Guillaumet/Y. Labaune: Les activités artisanales de Bibracte et d'Autun: une pérennité des savoir-faire. In: M. Reddé/ P. Barral/F. Favory/J.-P. Guillaumet/M. Joly/J.-Y. Marc/ $\mathrm{Ph}$. Nouvel/L. Nuninger/Ch. Petit (dir.): Aspects de la Romanisation dans l'Est de la Gaule 2. Collection Bibracte 21. Glux-en-Glenne 2011, 895-906.

Horálková 1990 - P. Horálková: Kovolitecká chata z laténského sídliště v Pavlově. In: V. Nekuda/J. Unger/ M. Čižmář (eds.): Pravěké a slovanské osídlení Moravy.
Sborník př́spěvků k osmdesátým narozeninám akademika Josefa Poulika. Brno 1990, 205-210.

Klanica 1971 - Z. Klanica: Laténské sídliště v Čejkovicích (okr. Hodonín). Přehled výzkumů 1970, 1971, 40.

Kostrouch 2011 - F. Kostrouch: Čejkovice (okr. Hodonín). Přehled výzkumů 52, 2011, 208.

Kysela 2016 - J. Kysela: Sitos - chrémata? Chalkos - eikona? K řeckým mincím ve střední Evropě mladší doby železné. Numismatický sborník 30, 2016, 193-227.

Kysela 2017 - J. Kysela: L'oppidum de Třísov (CZ). L'atelier de bronzier (?) fouillé en 1981-1982 et l'artisanat sur les acropoles des oppida en Europe centrale. In: S. Marion/S. Deffressigne/J. Kaurin/G. Bataille (dir.): Production et proto-industrialisation aux âges du Fer. Perspectives sociales et environnementales. Actes du $39^{\circ}$ colloque international de l'AFEAF Nancy, 14-17 mai 2015. Collection Mémoires 47. Bordeaux 2017, 467-474.

Lečbych/Mikulková 2014 - M. Lečbych/B. Mikulková: Laténské sídliště z Milonic (okr. Vyškov). In: J. Čižmářová/N. Venclová/G. Březinová (eds.): Moravské křižovatky. Střední Podunaji mezi pravěkem a historií. Brno 2014, 377-402.

Mangel/Jošková 2019 - T. Mangel/T. Jošková: East Bohemian Finds of Belt Segments with a Central Knob and Sites Plates as Evidence of Interregional Contacts during the La Tène period. In: N. Beljak Pažinová/ D. Repka (red.): Sedem kruhov Jozefa Bujnu. Studia Historica Nitriensia 23. Supplementum 2. Nitra 2019, 465-480.

DOI: https://doi.org/10.17846/SHN.2019.23.S.465-480

Meduna 1980 - J. Meduna: Die latènezeitlichen Siedlungen in Mähren. Praha 1980.

Píc 1906 - J. L. Píč: Le Hradischt de Stradonitz en Bohême. Leipzig 1906.

Rudnicki 2014 - M. Rudnicki: Nowa Cerekwia - the Middle La Tène centre of power north of the Carpathians. In: J. Čižmářová/N. Venclová/G. Březinová (eds.): Moravské křižovatky. Středni Podunají mezi pravěkem a historií. Brno 2014, 421-437.

Rybová/Drda 1994 - A. Rybová/P. Drda: Hradiště by Stradonice. Rebirth of a Celtic oppidum. Praha 1994.

Schäfer 2010 - A. Schäfer: Die Kleinfunde der jüngerlatènezeitlichen Siedlung von Berching-Pollanten, Lkr. Neumarkt i.d. Oberpfalz. Marburger Studien zur Vor- und Frühgeschichte 24. Rahden/Westf 2010.

Schäfer/Scharff 2003 - A. Schäfer/W. Scharff: The ceramics of a Celtic Bronze foundry from the Oppidum of Kelheim, Germany. In: S. Di Pierro/V. Serneels/ M. Maggetti (eds.): Ceramic in the Society. Proceedings of the $6^{\text {th }}$ European Meeting on Ancient Ceramics Fribourg, Switzerland, 3-6 October 2001. Fribourg 2003, 261-266.

Škojec 2000 - J. Škojec: Archäologische Fundstätten und Funde im „Hinterland“ des Burgwalls von Mikulčice IV (Katastralgebiete Čejkovice, Dolní Bojanovice, Josefov, Nový Poddvorov, Petrov, Prušánky, Starý Poddvorov, Strážnice, Sudoměřice, Vnorovy). In: L. Poláček (Hrsg.): Studien zum Burgwall von Mikulčice 4. Spisy Archeologického ústavu AV ČR Brno 18. Brno 2000, 405-495.

Trebsche 2010 - P. Trebsche: Auswertung der latènezeitlichen Befunde und Funde von Michelstetten. In: E. Lauermann (Hrsg.): Die latènezeitliche Siedlung 
von Michelstetten. Die Ausgrabungen des Niederösterreichischen Museums für Urgeschichte in den Jahren 1994-1999. Archäologische Forschungen in Niederösterreich 7. St. Pölten 2010, 15-115.

Trebsche et al. 2020 - P. Trebsche/J. M. Bagley/M. Karwowski/M. Kohler-Schneider/J. Militký/E. Pucher/ P. C. Ramsl/K. Wiltschke-Schrotta: Kontinuitäten, Neuerungen und Brüche. In: P. Trebsche (Hrsg): Keltische Münzstätten und Heiligtümer. Die jüngere Eisenzeit im Osten Österreichs (ca. 450 bis 15 v. Chr.). Wien 2020, 466-486.

Venclová 2001 - N. Venclová: Výroba a sídla v době laténské. Projekt Loděnice. Praha 2001.

Venclová ed. 2008 - N. Venclová (ed.): Archeologie pravěkých Čech 7. Doba laténská. Praha 2008.

Manuscript accepted 10. 3. 2021

Translated by Jan Kysela

Mgr. Petra Goláňová, Ph.D.

Ústav archeologie a muzeologie

Filozofická fakulta

Masarykova univerzita

Arna Nováka 1

CZ - 62000 Brno

golanova@phil.muni.cz
Waldhauser 1986 - J. Waldhauser: Kupfergewinnung und -verhüttung in Böhmen und Mähren während der Späthallstatt- und Latènezeit (Forschungsstand). In: B. Gramsch (Hrsg.): Siedlung, Wirtschaft und Gesellschaft während der jüngeren Bronze- und Hallstattzeit in Mitteleuropa. Internationales Symposium Potsdam, 25. bis 29. April 1983. Die Veröffentlichungen des Museums für Ur- und Frühgeschichte in Potsdam 20. Berlin 1986, 197-212.

Záruba 2015 - T. Záruba: Doklady barevné metalurgie na lokalitách doby laténské na území Čech a Moravy. Bakalářska diplomová práce. Masarykova univerzita v Brně. Filozofická fakulta. Ústav archeológie a muzeologie. Brno 2015. Online available at: https://is.muni.cz/th/ dv7ls/

Mgr. Miloš Hlava, Ph.D.

sekce archeologie Katedry historie Filozofická fakulta

Univerzita Palackého v Olomouci

Kř́ižkovského 10

CZ - 77180 Olomouc

mihlava@seznam.cz 
